\title{
É mais simples do que parece
}

MARIA CRistina S. Zelmanovits*

Meu pai me apresentou a terra e as sementes. Depois de algumas experiências no jardim da nossa casa, foi a vez de eu aprender na escola.

Lista das primeiras idéias que imagino ter formulado:

1. Semear é muito diferente de plantar.

2. Semear é amplo, plantar é íntimo.

3. Semear a gente corre o risco de não ver, plantar a gente vive.

4. Para plantar, a gente escolhe um pedacinho de terra boa, um pouco úmida e bem fofa;

daí cava uma espécie de berço;

deita a semente;

cobre, voltando a terra para o seu lugar (nessa hora, costuma aparecer uma certa preocupação com a provável claustrofobia da semente, mas a recordação do trabalho das minhocas faz passar);

joga um pouquinho de água por cima e espera.

(Pai é bom porque ensina a esperar com ternura. Esperar com ternura é assim: tempo para olhar, tempo para regar, tempo para acompanhar todo o crescimento. E pai é ainda melhor porque escolhe plantar feijão. E feijão cresce tão depressa que a gente troca ansiedade por alegria. Quando eu já sabia do feijão, meu pai veio com alguma semente mais demorada. Ele não precisou de muitas sementes para me ensinar a plantar. Recado à margem: até hoje, tenho mão boa para plantas).

\footnotetext{
* Maria Cristina S. Zelmanovits é Pedagoga, Assessora da Coordenação do CENPEC e já assessorou vários projetos de Literatura e Artes em escolas, museus e outras instituições.
}

5. Semear pode dar um trabalho danado:

há que se preparar muito a terra - revolver, adubar, medir,

cavar,

jogar as sementes (atenção: muitas sementes não podem disputar o mesmo espaço!),

cobrir com terra,

controlar matinhos e outras pragas,

regar,

acompanhar o crescimento,

colher.

Colher é a grande questão. Dá um prazer infinito brincar de cabo de guerra com o solo (solo vira sinônimo de terra quando semear é a palavra de ordem!).

6. Existem muitas formas de semear, pode até se usar máquinas.

Gostei mais de aprender os jeitos das abelhas, dos morcegos, dos pássaros e dos ventos.

O tempo passou e, de muitas outras formas, me vi às voltas com sementes durante a vida: abri para ver por dentro, tomei café com cardamomo, conversei com gente que trabalha na terra, li sobre os benefícios de algumas sementes para a saúde, fiquei interessada em sementes de flores, visitei plantações, soube da história dos escravos e do café...

Mas tudo isso na perspectiva do plantar. Só fiz as pazes com a semeadura de verdade lá em Juazeiro, em 2005. Vou contar como foi.

Fui chamada para ouvir e analisar a fala de uma professora. Entendi que seria o relato de um projeto já rea- 
lizado por ela junto aos alunos (adoro ouvir professora contando o que fez com os alunos!).

Ledo engano: o projeto ainda nem havia sido realizado e quem apresentaria o planejamento do projeto seria a coordenadora. Não gostei muito da mudança, porém, procurei me refazer com disponibilidade de ouvinte interessada.

... A gente vai ensinar os nomes científicos e as características das plantas que os alunos conhecem e que fazem parte de seu cotidiano... Eles vão ler, escrever, pesquisar...

Apresentação séria, dedicada, mas que não grudou em mim.

Até que, rompendo minha já quase desatenção, ouvi a seguinte delicadeza, nascida do único minuto em que a professora falou:

Uma das atividades de nosso projeto Aprendendo a Semear é a da pipa. A gente vai chamar os pais dos alunos para ensinar a fazer pipa. Os alunos vão construir pipas e vamos trabalhar com geometria, medição, texto com as regras de como se faz o brinquedo, arte...

(Pensei: "Puxa, tenho que falar com ela sobre Volpi”). Interessadíssima, não me contive:

- Mas o que as pipas têm a ver com o projeto Aprendendo a Semear?

\section{E a professora:}

As pipas vão carregar sementes e quando os meninos soltarem, tudo vai se espalhar.

Fiquei pensando na delícia de aprender a semear com pipas. Quis mesmo ser aluna dessa professora! Quanta doçura para explicar um conceito, quanta poesia, quanta brincadeira. Fiquei com vontade de aprender, desse jeito, matemática, leitura de textos de instrução (até hoje não gosto de seguir receitas e detesto manuais), relação cor/forma. Fiquei com vontade de aprender a fazer pipa com pai. Fiquei com vontade de ver planta nascendo da dança da pipa com o vento.

Se não tive a chance de voltar na máquina do tempo, ao menos pude rever minhas idéias sobre semear e, mais que isso, relembrar que aprender pode ser leve, gratuito. Às vezes, aprender até voa. 


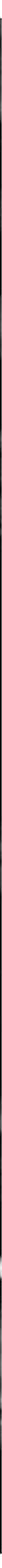

